\title{
Alteration of Lipid Metabolism Related Proteins in Liver of High-Fat Fed Obese Mice
}

\author{
Eunhui Seo, Ying Han, So-Young Park, Hyongjong Koh and Hye-Jeong Lee* \\ Department of Pharmacology, Medical Science Research Center, Dang-A University College of Medicine, Busan 602-714, Korea
}

Received May 13, 2010 /Accepted May 24, 2010

\begin{abstract}
Obesity and being overweight are strongly associated with the development of metabolic disease such as diabetes, hypertension, dyslipidemia. High-fat diet (HFD) is one of the most important factors which cause obesity. In this study, C57BL/6 mice were treated with a HFD for 22 weeks in order to induce obesity and hyperglycemia. Twenty-two weeks later, body weight and plasma glucose level of the HFD group were significantly increased, compared with the normal diet (ND) group. Intra-peritoneal glucose tolerance test (IPGTT) showed glucose intolerance in the HFD group compared with the ND group. These results confirmed that a HFD induced obesity and hyperglycemia in C57BL/6 mice. Plasma levels of triglyceride (TG) and total cholesterol (TC) were increased in the HFD group compared with the ND group. Hepatic levels of TG and TC were also increased by a HFD. To investigate the alteration of lipid metabolism in liver, proteins which are related to lipid metabolism were observed. Among lipid synthesis related enzymes, fatty acid synthase (FAS) and glycerol phosphate acyl transferase (GPAT) were significantly increased in the HFD group. Apolipoprotein B (apoB) and microsomal triglyceride transport protein (MTP), which are related to lipid transport, were significantly increased in the HFD group. Interestingly, protein level and phosphorylation of AMP-activated protein kinase (AMPK), which is known as a metabolic regulator, were significantly increased in the HFD group compared with the ND group. In the present study we suggest that HFD may physiologically increase the proteins which are related with lipid synthesis and lipid transport, but that HFD may paradoxically induce the activation of AMPK.
\end{abstract}

Key words : High fat diet, lipid metabolism, triglyceride

\section{Introduction}

High-fat diet (HFD) has contributed to the accumulation of adipose tissue, resulting in obesity, which is one of the most metabolic disorders in developing and developed countries. Particularly, a shift from a low-fat diet to a high-fat diet in developing countries, including South Korea, markedly increased in the prevalence of obesity in the last two decades [12,19]. Weight gain and obesity are major risk factors for conditions and diseases ranging from insulin resistance and type 2 diabetes mellitus (T2D) to atherosclerosis and the sequelae of nonalcoholic fatty liver disease [30]. Additionally, obesity is one of the most important risk factors for complex and chronic liver disorder [11]. These liver disorders begin as steatosis and may progress to steatohepatitis, cirrhosis, liver failure, and hepatocellular carcinoma $[2,20]$. It has been previously reported that insulin-resistant T2D and hyperlipidemia occur in most liver disease cases

*Corresponding author

Tel : +82-51-240-2859, Fax : +82-51-241-0778

E-mail : hjlee@dau.ac.kr
[32]. It means that obesity, insulin resistance and liver failure, all of three, are closely connected. The liver plays a central role in the control of glucose and lipid metabolism. When a high-carbohydrate meal is ingested, several metabolic events aimed at decreasing endogenous glucose production by the liver (glycogenolysis and gluconeogenesis) and increasing glucose uptake (glycolysis) and storage in the form of glycogen in the liver are turned on. In addition, when glucose is delivered into the portal vein in large quantities and once hepatic glycogen concentrations are restored, glucose can be converted in the liver into TG through de novo lipogenesis. In fact, TG represents the principal energy storage fuel in mammals. Lipids are essential for energy homeostasis, reproductive and organ physiology, and numerous aspects of cellular biology. They are also linked to many pathological processes, such as obesity, diabetes, heart disease, and inflammation [5]. In particular, glucose and fatty acids are able to regulate hepatic gene expression in a transcriptional manner.

The synthesis of TG in liver is nutritionally regulated, and its formation from simple carbohydrates requires multiple 
metabolic pathways, including glycolysis and pyruvate oxidation to generate acetyl-CoA for fatty acid synthesis, NADPH generation to supply the reductive power, packaging of fatty acids into a glycerophosphate backbone, and finally, lipoprotein packaging to export TG. Hepatic TG is produced by several key enzyme, including (i) ATP citrate lyase [6], ACC [15] and FAS [16] for lipogenesis; (ii) long-chain elongase (LCE) (also known as ELOVL6) [13] and stearoyl-CoA desaturase 1 (SCD1) [22] synthesizing for fatty acid elongation and desaturation steps; and finally (iii), mitochondrial GPAT and diacylglycerol acyltransferase (DGAT) for TG synthesis [29]. It is widely accepted that hepatic lipid availability is obligatory for apoB-containing lipoprotein assembly within the liver, a finding supported by studies demonstrating the necessity of TG $[7,27]$ and phospholipid [35]. The hepatic production of apoB-containing lipoproteins is regulated largely, with nascent apoB molecules being secreted or degraded intracellularly [36]. The assembly of apoB with lipid to form a secretion-competent particle is a complex process $[7,36]$. The availabilities of cholesterol and cholesterol esters, synthesized by the HMG-CoA reductase (HMGCR) pathway, have also been shown to be important determinants of the rate of hepatic apoB secretion $[3,4,34]$. The MTP also plays a key role in apoB secretion by catalyzing the transfer of lipids to the nascent apoB molecule as it is cotranslationally translocated across the endoplasmic reticulum membrane $[14,33]$.

The aims of the present study were as follows: 1 ) to develop an obesity mouse model fed with HFD, 2) to investigate the alteration of hepatic proteins which are associated with the lipid metabolism under the normal or high-fat diet condition. The results of this study might be basic information for understanding the connection of obesity, diabetes and lipid disorder, and searching for therapeutic targets of the metabolic disorder.

\section{Materials and Methods}

\section{Animal treatment}

Male, 6 weeks old C57BL/ 6 inbred mice weighing 22-25 g were supplied by Samtako Bio Korea (Kyoung-Ki, South Korea). All mice were maintained in room under controlled temperature $\left(22^{\circ} \mathrm{C}\right)$, humidity $(50 \%)$, and air-flow condition, with a fixed $12 \mathrm{hr}$ light-dark cycle. Mice were provided with food and water in ad libitum during 2 weeks for acclimatization. Mice were classified into two groups and fed with the normal (ND) and high-fat diet (HFD) (protein $14.3 \%$, carbohydrate $20.1 \%$, and fat $64.4 \%$ (kcal \%)) for up to 22 weeks. All period of experiment, body weight and food intake are measured daily, except weekend. Tissue samples were frozen immediately using liquid nitrogen and were stored at $-70^{\circ} \mathrm{C}$ until assayed.

\section{Intraperitoneal glucose tolerance test (IPGT)}

After 22 weeks ND or HFD feeding, the mice were fasted for $6 \mathrm{hr}$ following intraperitoneal injection with glucose (1 $\mathrm{mg} / \mathrm{g}$ body weight), and blood glucose levels were measured at $0,5,10,30,60$ and $120 \mathrm{~min}$ post injection.

\section{Measurements of blood glucose, plasma lipids and GOT/GPT}

Blood samples were collected to measure glucose, total cholesterol (TC), and triglyceride (TG) levels. The sampling line was filled with $4.5 \%$ EDTA to prevent blood clotting. Samples were kept on ice, and plasma was isolated using centrifuagation and stored at $-20^{\circ} \mathrm{C}$ until analysis. Glucose levels were measured with a glucose analyzer, GlucoDR (Allmedicus, An-Yang, South Korea). TC and TG levels were measured with the ASAN Set Total-cholesterol Reagent and Triglyceride-S Reagent (ASAN PHARM., Seoul, South Korea), respectively. Glutamic oxaloacetic transaminase (GOT)/ glutamic-pyruvate transaminase (GPT) were measured with the ASAN set GOT.GPT Reagent by ReitmanFrankel method (ASAN PHARM.).

\section{Analysis of hepatic lipids}

Liver samples were lysed in ethanolic $\mathrm{KOH}$ (2 parts EtOH: 1 part $30 \% \mathrm{KOH}$ ) and incubated overnight at $55^{\circ} \mathrm{C}$. The lysates were mixed with $\mathrm{H}_{2} \mathrm{O}: \mathrm{EtOH}$ (1:1) and centrifuged for $5 \mathrm{~min}$. The supernatant was mixed with $1 \mathrm{M}$ $\mathrm{MgCl}_{2}$, incubated for $10 \mathrm{~min}$ on ice and centrifuged for 5 min. The resulting supernatant was used to measure TG or TC.

\section{Immunoblotting}

Total proteins were isolated form liver sample using radioimmunoprecipitation assay (RIPA) buffer containing 50 $\mathrm{mM}$ Tris- $\mathrm{HCl}, \mathrm{pH}$ 8.0, with $150 \mathrm{mM}$ sodium chloride, $1.0 \%$ Igapal CA-630 (NP-40), 0.5\% sodium deoxycholide, $0.1 \%$ sodium dodesyl sulfate, protease Inhibitor Cocktail (P8340; Sigma, St Louis, MO, USA) and Phosphatase Inhibitor Cocktails (P2850 and P5726, Sigma). The lysates were centri- 
fuged at 13,000 rpm for $30 \mathrm{~min}$ to remove insoluble debris. Supernatants were collected and assayed for protein content prior to storage at $-70^{\circ} \mathrm{C}$. Protein concentration was determined in triplicate using the bicinchoninic acid solution (B9643, Sigma) with cooper (II) surfate solution (C2284, Sigma).

Protein sample were mixed Laemmli Sample Buffer (LSB) and placed in a boiling water bath for $5 \mathrm{~min}$. Proteins were resolved by 6 or $10 \%$ SDS-polyacrylamide gel electrophoresis (SDS-PAGE; each loaded with same $\mu \mathrm{g}$ of total protein per lane), and transferred to nitrocellulose membranes. Blots were probed with antibodies to ACC Antibody (\#3662; $280 \mathrm{kDa}$ ) and Phospho-ACC (Ser79) Antibody (\#3661; 280 kDa) (Cell Signaling Technology), Actin (I-19) (sc-1616; 43 kDa), HMGCR (C-18) (sc-27578; 43 kDa), SCD1 (E-15) (sc-14720; $37 \mathrm{kDa}$ ), MTP (N-17) (sc-33116; $97 \mathrm{kDA})$, Fatty Acid Synthase (H-300) (sc-20140; $270 \mathrm{kDa}$ ) and DGAT2 (H-70) (sc-66859; 44 kDa) (Santa Cruz Biotechnology Inc., Santa Cruz, CA), Rabbit polyclonal to apoB (ab20737; 549 $\mathrm{kDa}$; Abcam, Cambridge, MA) and AMPK alpha1 antibody (A300-507A; 62 kDa; Bethyl Laboratories, Inc., Montgomery, TX). Membrane were developed using horseradish peroxidase-conjugated donkey anti-rabbit (NA934; GE Healthcare, Chalfont, St Giles, UK), and donkey anti-goat IgG (sc-2056; Santa Cruz Biotechnology Inc.), followed by incubation with ECL PlusTM Western Blotting Detection Reagents (RPN2135; GE Healthcare, Chalfont, St Giles, UK), and signals were detected using a Fuji LAS 3000 Imaging station (Fuji Photo Film, Fuji, Japan).

\section{Statistical analysis}

Results are expressed as means \pm SEM. Differences between groups were analyzed by paired or non-paired Student's $t$ test. Differences were considered significant when the $p$ value was less than 0.05 .

\section{Results}

Obese and hyperglycemic mice model by feeding with HFD

For inducing obesity and hyperglycemia, animals were treated with HFD for 22 weeks. Body weight was measured daily, except weekend. After 9 weeks of treatment with HFD, a difference in body weight was observed (Fig. 1A). Twenty-two weeks later with ND or HFD, body weight of ND group was $33.58 \pm 0.38 \mathrm{~g}$. On the other hand, that of HFD group was $40.83 \pm 0.89 \mathrm{~g}$; differences were significant (Fig. 1B). Blood glucose levels of both fasting and random glucose increased in HFD group (Fig. 1C and 1D). Fasting glucose level was $103.20 \pm 3.30 \mathrm{mg} / \mathrm{dl}$ in ND group, and 171.69 \pm 4.02 $\mathrm{mg} / \mathrm{dl}$ in HFD group (Fig. $5 \mathrm{C}$ ). In the same manner, random glucose level was $147.15 \pm 23.86 \mathrm{mg} / \mathrm{dl}$ in ND group, and $188.72 \pm 5.43 \mathrm{mg} / \mathrm{dl}$ in HFD group (Fig. 5D). Analysis of IPGTT also showed significant differences between ND and HFD groups. Especially, later at 90 and 120 min following glucose injection, plasma glucose was significantly higher in HFD group than in ND group (Fig. 1E).

GOT/GPT measurement for verification of hepatic toxicity by HFD

To examine that HFD itself causes cytotoxicity, verification of toxicity of the liver and several other organs was necessary. GOT is raised in acute liver damage. It is also present in red blood cells, cardiac muscle, skeletal muscle, kidney and brain tissue, and may be elevated due to damage to those sources as well. GPT is commonly measured clinically as a part of diagnostic liver function testing for determination of liver health, because, compared with GOT, GPT is located in liver more than in other organs. The normal range for GOT is $8-40 \mathrm{karmen} / \mathrm{ml}$, and GPT is $5-30 \mathrm{kar}-$ $\mathrm{men} / \mathrm{ml}$. The HFD itself induced a significantly increase of both GOT and GPT levels. Plasma level of GOT was $9.70 \pm 3.57 \mathrm{karmen} / \mathrm{ml}$ in ND group, but $41.88 \pm 6.79$ kar$\mathrm{men} / \mathrm{ml}$ in HFD group. Plasma level of GPT was $4.46 \pm 1.68$ karmen $/ \mathrm{ml}$ in ND group, but $10.61 \pm 2.75 \mathrm{karmen} / \mathrm{ml}$ in HFD group (Fig. 2). However, the increment induced by HFD was within normal range. These results suggest that hepatic toxicity may not be induced significantly by HFD.

\section{Changes of lipid parameters by HFD}

To determine the alteration of plasma and hepatic lipids by HFD, lipid profile analysis performed. The HFD group showed a high plasma levels of TG and TC compared with the ND group. Plasma level of TG was $46.3 \pm 2.1 \mathrm{mg} / \mathrm{dl}$ in ND group, but $60.6 \pm 4.9 \mathrm{mg} / \mathrm{dl}$ in HFD group (Fig. 3). Plasma level of TC was $106.6 \pm 4.7 \mathrm{mg} / \mathrm{dl}$ in ND group, but $158.5 \pm 7.8 \mathrm{mg} / \mathrm{dl}$ in HFD group (Fig. 3). Hepatic lipids were also higher at HFD group than ND group. Hepatic level of TG was $89.2 \pm 5.8 \mathrm{mg} / \mathrm{g}$ in ND group, but $191.4 \pm 20.7 \mathrm{mg} / \mathrm{g}$ in HFD group (Fig. 3). Hepatic level of TC was $26.4 \pm 4.6$ $\mathrm{mg} / \mathrm{g}$ in ND group, but $59.7 \pm 8.9 \mathrm{mg} / \mathrm{g}$ in HFD group condition (Fig. 3). These results indicated that HFD induced hy- 

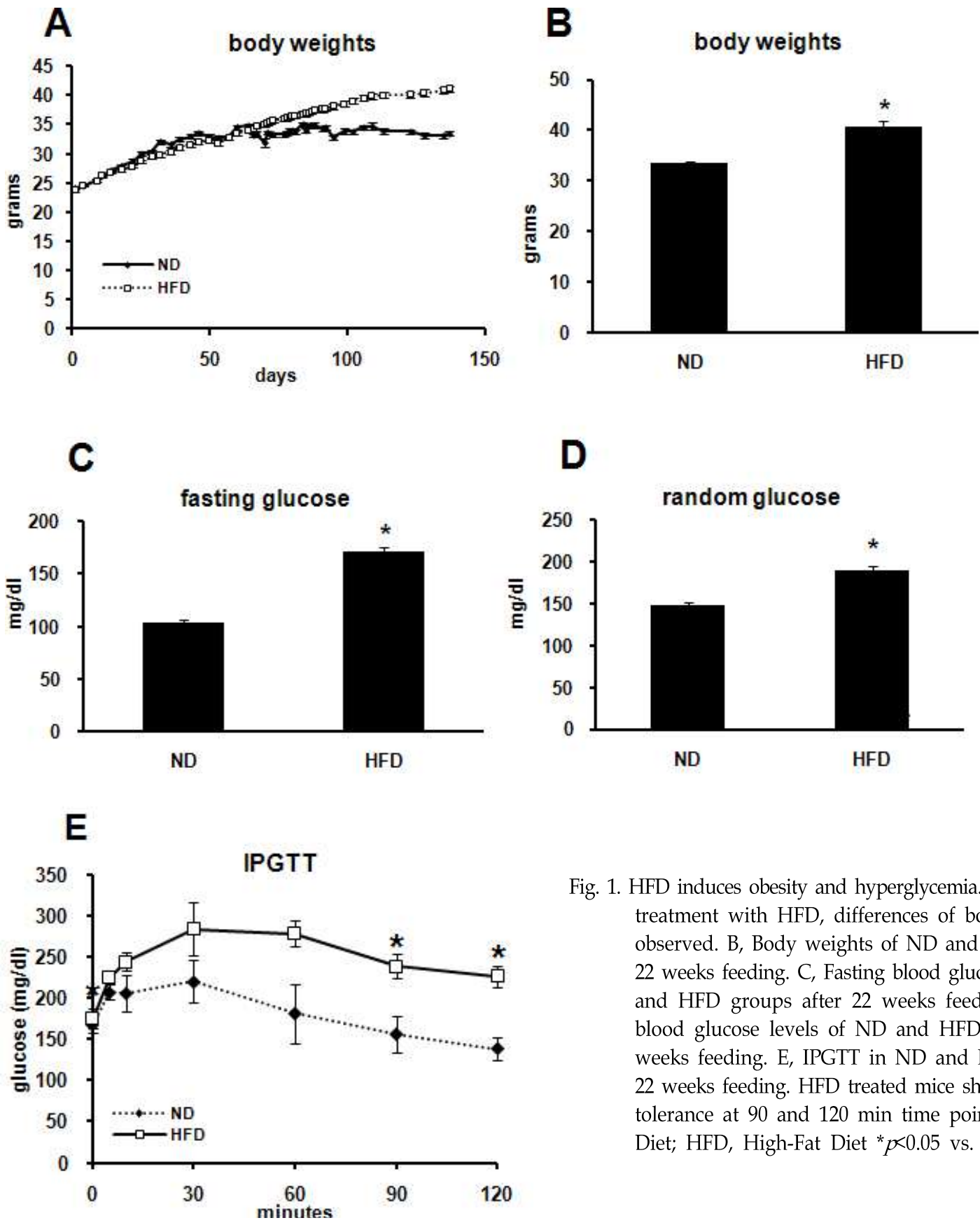

Fig. 1. HFD induces obesity and hyperglycemia. A, 9 weeks after treatment with HFD, differences of body weight were observed. B, Body weights of ND and HFD groups for 22 weeks feeding. C, Fasting blood glucose levels of ND and HFD groups after 22 weeks feeding. D, Random blood glucose levels of ND and HFD groups after 22 weeks feeding. E, IPGTT in ND and HFD group after 22 weeks feeding. HFD treated mice showed glucose intolerance at 90 and 120 min time points. ND, Normal Diet; HFD, High-Fat Diet ${ }^{*} p<0.05$ vs. normal diet.

perlilpidemia and fatty liver.

\section{Changes of lipid metabolism-related proteins by HFD}

To verify protein expression associated with lipid metabolism, we performed western blotting with liver tissues of both ND and HFD groups (Fig. 4). Proteins involved in lipid synthesis, ACC, FAS, SCD1, GPAT, HMGCR and DGAT2 were checked (Fig. 4A). Protein levels of FAS and GPAT were higher in HFD than ND group. Protein levels of ACC and SCD1 showed tendency of increase, but statistically non-significant $(P=0.051, P=0.093$, respectively) Protein levels of apoB and MTP, which are associated with lipid exocytosis, were significantly increased in HFD compared with ND group (Fig. 4B). Protein levels of AMPK known as a metabolic regulator were unexpectedly increased and the phosphorylation of AMPK activated in HFD group compared to ND group. ACC which is a major substrate of AMPK was also phosphorylated in HFD group more than ND group. 


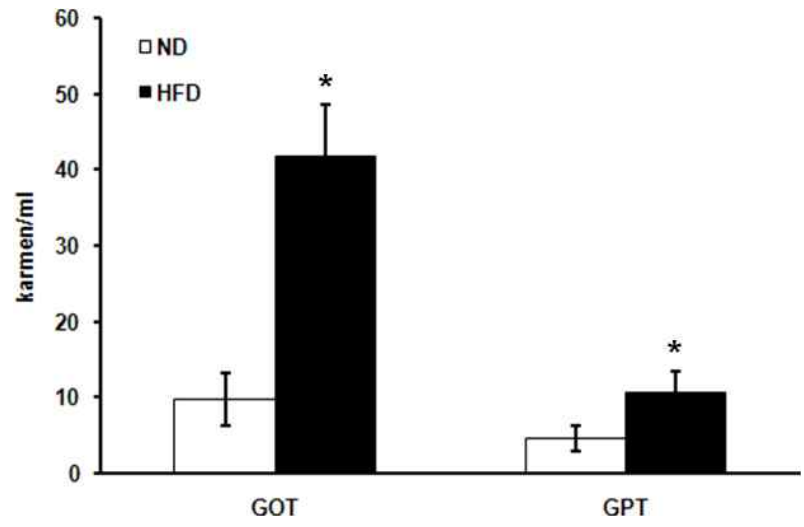

Fig. 2. Analysis of hepatic toxicity. GOT/GPT levels were increased in HFD group, but within normal limit. * $p<0.05$ vs. normal diet.

\section{Discussion}

Weight gain and obesity are major risk factors for conditions and diseases ranging from insulin resistance and T2D to atherosclerosis [30]. The prevalence of liver disorders is high in obese people, and in patients who have T2D, insulin

Plasma TG

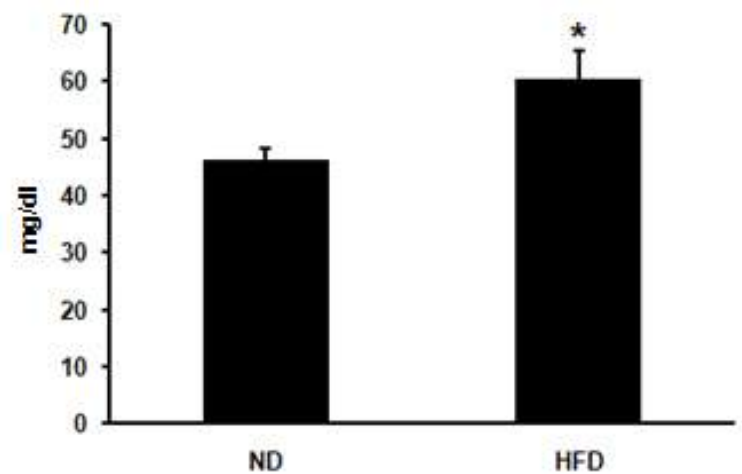

Plasma TC

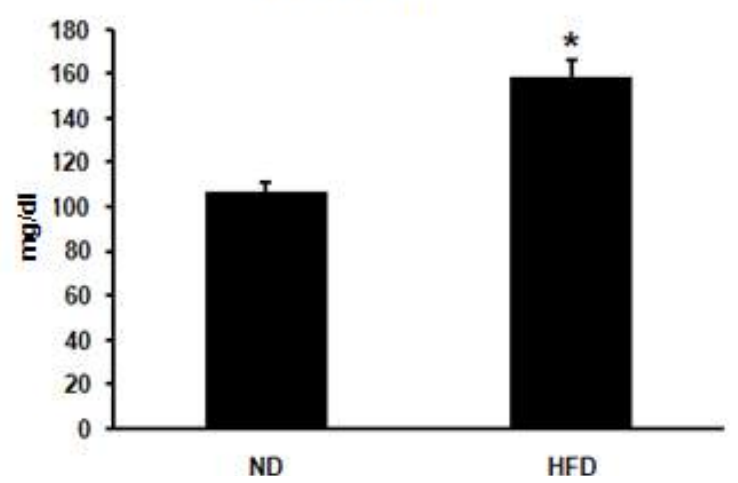

resistance is one of the key elements leading to liver disease in obese people [21]. Obesity is continuous with T2D $[23,25,28]$.

The present study investigated the alteration of lipid metabolism related proteins in obese C57BL/6 mice induced by HFD. To confirm that HFD was successfully induced obesity and T2D, the body weight and blood glucose level were measured (Fig. 1A-D). Difference of Body weight was observed after 9 weeks of treatment with HFD (Fig. 1A). Fasting and random blood glucose were also higher in HFD group than ND group (Fig. 1C, D). The result from IPGTT confirmed glucose intolerance in HFD group (Fig. 1E). These results mean that feeding of HFD during 22 weeks induced obesity and T2D. Levels of plasma and hepatic lipids were also significantly higher in HFD than ND group (Fig. 3). It means that as already known HFD induced not only obesity and hyperglycemia, but also hyperlipidemia and fatty liver in this study.

Because HFD induced obesity and fatty liver, plasma levels of GOT/GPT were measured for knowing whether HFD

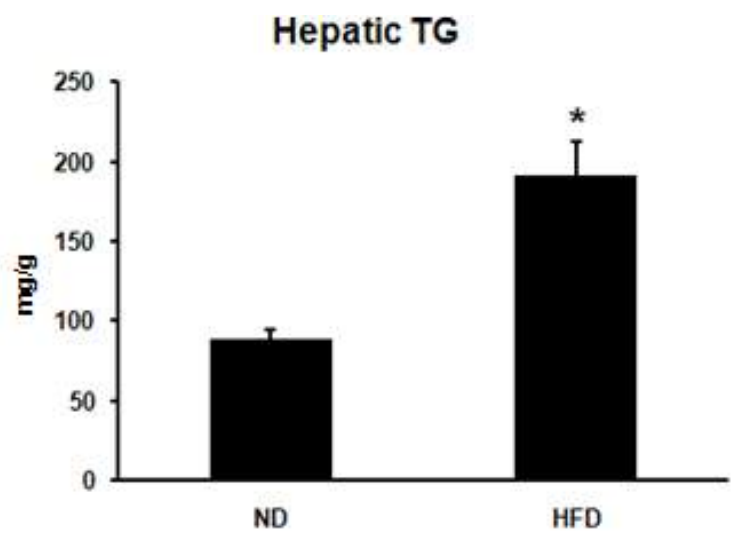

Hepatic TC

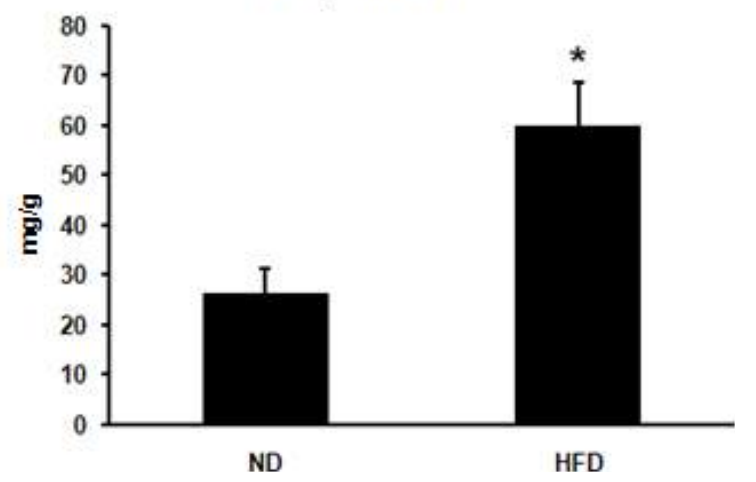

Fig. 3. Measurement of plasma and hepatic lipid levels. Plasma and hepatic concentrations of TG and was increased in HFD group compared with ND group after 22 weeks feeding. * $p<0.05$ vs. normal diet. 
itself may cause cytotoxicity. The levels of GOT/GPT in HFD group were significantly higher than ND group, although levels of GOT/GPT stayed within normal range in both ND and HFD groups. It means that HFD itself does not trigger cytotoxicity even though the numerical value was slightly increased in HFD group.

Hepatic TG synthesis is conducted in the order of ACC-FAS-SCD1-GPAT-DGAT2 [26]. The present study shows the comparison of the protein levels related with hepatic TG synthesis between ND and HFD. The protein levels of FAS and GPAT were increased in HFD group (Fig. 4A). FAS is the enzyme catalyzing the terminal steps in the de novo biosynthesis of long-chain fatty acids. FAS activity has been shown to significantly influence energy expenditure rates, fat mass, insulin sensitivity and cancer risk [36]. GPAT, which catalyzes the initial and committing step in glycerolipid biosynthesis, is predicted to play a pivotal role in the regulation of cellular triacylglycerol and phospholipid levels [17]. This result is corresponded with present of hyperlipidemia and fatty liver in this study.

ApoB and MTP are necessary for lipoprotein assembly and exocytosis [8]. Lipid transfer activity of MTP is required for the assembly of lipoproteins. This activity renders nascent apoB secretion-competent and may be involved in the import of triglycerides into the lumen of endoplasmic reticulum $[1,8,24]$. In this study, protein levels of apoB and MTP were increased by HFD (Fig. 4B). Therefore, increased protein levels of apoB and MTP by HFD is thought to induce exocytosis of lipoprotein. This hypothesis harmonized with our results, increase of both hepatic and plasma lipid (Fig. 3).

AMPK is thought to act as a cellular 'fuel gauge' or 'metabolic switch' and has been suggested to play an important role in glucose and lipid metabolism $[9,10]$. The expression and activity of AMPK are generally suppressed with HFD for short-term period [37]. In this study, AMPK protein level and activity were increased by HFD (Fig. 4C). This is unexpected result and the discrepancy might be caused by the feeding duration of HFD. HFD experiment is commonly attempted for 5-10 weeks while this study performed it for 22 weeks. The long period HFD induced high plasma and hepatic lipids. It is thought to a compensatory action to reverse the increased concentration of plasma and hepatic lipids. The enzyme might serve as a metabolic switch, decrease fatty acid synthesis and increase fatty acid oxidation.

In summary, C57BL/6 mice fed HFD during 22 weeks induce obesity, hyperglycemia, hyperlipidemia and fatty
A

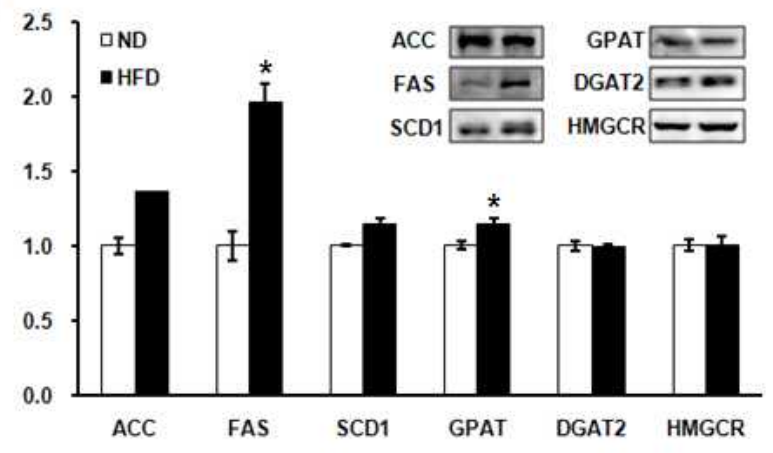

B

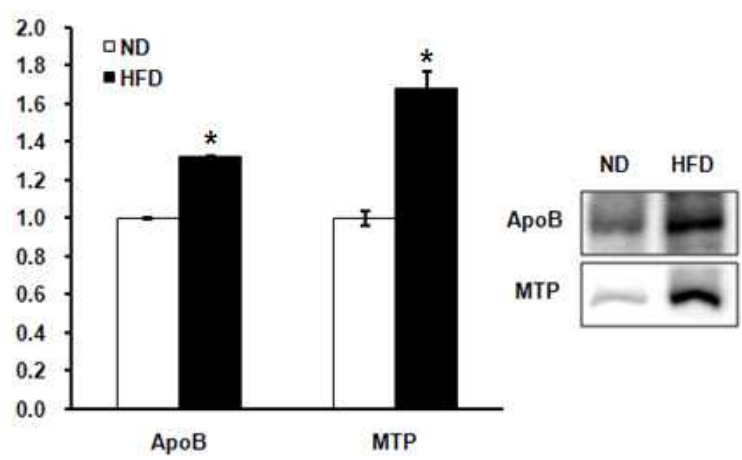

C

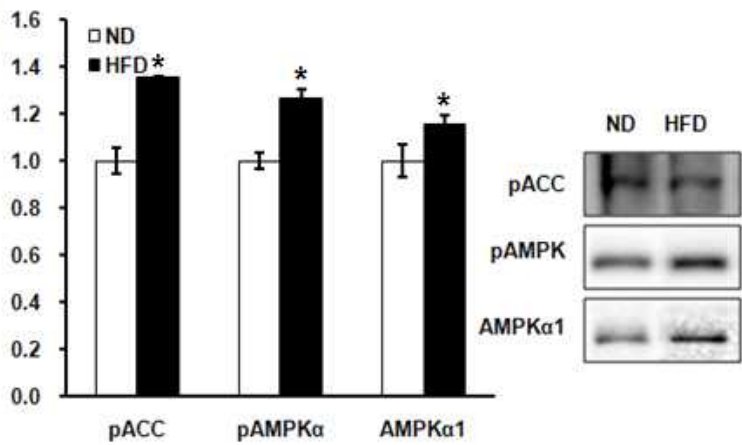

Fig. 4. Analysis of immunoblots with proteins associated with lipid metabolism by HFD. A, Protein levels related with lipid synthesis. Protein levels of FAS and GPAT were increased by HFD. B, Protein levels related with lipid transfer. Protein levels of ApoB and MTP were also increased by HFD. C, Protein levels of AMPK and phosphorylation of AMPK and ACC. AMPK, PAMPK and pACC were increased by high-fat diet. ${ }^{*} p<0.05$ vs. normal diet.

liver. The increase of hepatic lipid synthesis and exocytosis by HFD is considered that these phenomena might be caused excessive supplementation of high fat. To rectify these metabolic phenomena, AMPK protein level and activity might be increased. Therefore, we suggest that early activation of AMPK might be better targets for amelioration of high-fat diet induced obesity. These differential expression of lipid metabolism related proteins may be applied to the 
development of therapeutic targets for obesity and hyperglycemia treatment.

\section{Acknowledgement}

This paper was supported by Dong-A University Research Fund in 2007.

\section{References}

1. Berriot-Varoqueaux, N. L. P., A. M. Samson-Bouma, and J. R. Wetterau. 2000. The role of the microsomal triglygeride transfer protein in abetalipoproteinemia. Annu. Rev. Nutr. 20, 663-697.

2. Bugianesi, E., P. Manzini, S. D'Antico, E. Vanni, F. Longo, N. Leone, P. Massarenti, A. Piga, G. Marchesini, and M. Rizzetto. 2004. Relative contribution of iron burden, HFE mutations and insulin resistance to fibrosis in non alcoholic fatty liver. Hepatology 39, 179-187.

3. Burnett, J. R., L. J. Wilcox, D. E. Telford, S. J. Kleinstiver, P. H. R. Barrett, R. S. Newton, and M. W. Huff. 1999. Inhibition of ACAT by avasimibe decreases both VLDL and LDL apolipoprotein B production in miniature pigs. J. Lipid Res. 40, 1317-1327.

4. Cianflone, K., Z. Yasruel, M. A. Rodriguez, D. Vas, and A. D. Sniderman. 1990. Regulation of apoB secretion from HepG2 cells: evidence for a critical role for cholesteryl ester synthesis in the response to a fatty acid challenge. J. Lipid Res. 31, 2045-2055.

5. Dentin, R., P. D. Denechaud, F. Benhamed, J. Girard, and C. Postic. 2006. Hepatic gene regulation by glucose and polyunsaturated fatty acids: a role for ChREBP. J. Nut. 136, 1145-1149.

6. Elshourbagy, N. A., J. C. Near, P. J. Kmetz, G. M. Sathe, C. Southan, J. E. Strickler, M. Gross, J. F. Young, T. N. Wells, and P. H. Groot. 1990. Rat ATP citrate-lyase. Molecular cloning and sequence analysis of a full-length cDNA and mRNA abundance as a function of diet, organ, and age. J. Biol. Chem 265, 1430-1435.

7. Ginsberg, H. N. 1997. Role of lipid synthesis, chaperone proteins and proteasomes in the assembly and secretion of apoprotein Bcontaining lipoproteins from cultured liver cells. Clin. Exp. Pharmacol. Physiol. 24, A29-A32.

8. Gordon, D. A. and H. Jamil. 2000. Progress towards understanding the role of microsomal triglyceride transfer protein in apolipoprotein-B lipoprotein assembly. Biochim Biophys. Acta. 1486, 72-83.

9. Hardie, D. G. 2004. AMP-activated protein kinase: a master switch in glucose and lipid metabolism. Rev. Endocr. Metab. Disord 5, 119-125.

10. Hardie, D. G., J. W. Scott, D. A. Pan, and E. R. Hudson. 2003. Management of cellular energy by the AMP-activated protein kinase system. FEBS Lett 546, 113-120.

11. Haynes, P., S. Liangpunsakul, and N. Chalasani. 2004.
Nonalcoholic fatty liver disease in individuals with severe obesity. Clin. Liver Dis. 8, 535-547.

12. Hedley, A. A., C. L. Ogden, C. L. Johnson, M. D. Carroll, L. R. Curtin, and K. M. Flegal. 2004. Prevalence of overweight and obesity among US children, adolescents, and adult, 1999-2002. JAMA 291, 2847-2850

13. Jakobsson, A., R. Westerberg, and A. Jacobsson. 2006. Fatty acid elongases in mammals: their regulation and roles in metabolism. Prog. Lipid Res. 45, 237-249.

14. Jamil, H., J. K. Dickson, Jr., C. Chu, M. W. Lago, J. K. Rinehart, S. A. Biller, R. E. Gregg, and J. R. Wetterau. 1995. Microsomal triglyceride transfer protein: specificity of lipid binding and transport. J. Biol. Chem 270, 6549-6554.

15. Katsurada, A., N. Iritani, H. Fukuda, Y. Matsumura, N. Nishimoto, T. Noguchi, and T. Tanaka. 1990. Effects of nutrients and hormones on transcriptional and post-transcriptional regulation of acetyl-CoA carboxylase in rat liver. Eur. J. Biochem 190, 435-441.

16. Katsurada, A., N. Iritani, H. Fukuda, Y. Matsumura, T. Noguchi, and T. Tanaka. 1989. Effects of nutrients and insulin on transcriptional and post-transcriptional regulation of glucose-6-phosphate dehydrogenase synthesis in rat liver. Biochim Biophys. Acta. 1006, 104-110.

17. Lewin, T. M., S. Wang, C. A. Nagle, C. G. Van Horn, and R. A. Coleman. 2005. Mitochondrial glycerol-3-phosphate acyltransferase- 1 directs the metabolic fate of exogenous fatty acids in hepatocytes. Am J. Physiol. Endocrinol. Metab. 288, E835-E844.

18. Menendez, J. A., A. Vazquez-Martin, F. J. Ortega, and J. M. Fernandez-Real. 2990. Fatty Acid Synthase: Association with Insulin Resistance, Type 2 Diabetes, and Cancer. Clin. Chem 55, 425-438.

19. Mokdad, A. H., E. S. Ford, and B. A. Bowman, W. H. Dietz, F. Vinicor, V. S. Bales, J. S. Marks. 2003. Prevalence of obesity, diabetes, and obesity-related health risk factors. JAMA 289, 76-79.

20. Mori, S., T. Yamasaki, I. Sakaida, T. Takami, E. Sakaguchi, T. Kimura, F. Kurokawa, S. Maeyama, and K. Okita. 2004. Hepatocellular carcinoma with nonalcoholic steatohepatitis. J. Gastroenterol. 39, 391-396.

21. Nicol, C. J., M. Adachi, T. E. Akiyama, and F. J. Gonzalez. 2005. ARgamma in endothelial cells influences high fat diet-inducedhypertension. Am J. Hypertens 18, 549-556.

22. Ntambi, J. M. 1992. Dietary regulation of stearoyl-CoA desaturase 1 gene expression in mouse liver. J. Biol. Chem 267, 10925-10930.

23. Olefsky, J. M., O. G. Kolterman, and A. Scarlett. 1982. Insulin action and resistance in obesity and noninsulin-dependent type II diabetes mellitus. Am J. Physiol. Endocrinol. Metab. 243, E15-E30.

24. Olofsson, S. O., L. Asp, and J. Boren. 1990. The assembly and secretion of apolipoprotein B-containing lipoproteins. Curr. Opin. Lipido. 10, 341-346.

25. Pinkney, J. 2002. Prevention and cure of type 2 diabetes, BMJ 325, 232-233

26. Postic, C. and J. Girard. 2008. Contribution of de novo fatty acid synthesis to hepatic steatosis and insulin resistance: les- 
sons from genetically engineered mice. J. Clin. Invest. 118, 829-838.

27. Pullinger, C. R., J. D. North, B. B. Teng, V. A. Rifici, A. E. Ronhild de Brito, and J. Scott. 1989. The apolipoprotein B gene is constitutively expressed in HepG2 cells: regulation of secretion by oleic acid, albumin, and insulin, and measurement of the mRNA halflife. J. Lipid Res. 30, 1065-1077.

28. Reaven, G. M. 1988. Banting lecture. Role of insulin resistance in human disease. Diabetes 37, 1595-1607.

29. Saha, A. K., P. R. Avilucea, J. M. Ye, M. M. Assifi, E. W. Kraegen, and N. B. Ruderman. 2004 Pioglitazone treatment activates AMP-activated protein kinase in rat liver and adipose tissue in vivo. Biochem Biophys. Res. Commun. 314, 580-585.

30. Shoelson, S. E., L. Herrero, and A. Naaz. 2007. Obesity, inflammation, and insulin resistance. Gastroenterology 132, 2169-2180.

31. Tao, R., F. Ye, Y. He, J. Tian, G. Liu, T. Ji, and Y. Su. 2009. Improvement of high-fat-diet-induced metabolic syndrome by a compound from Balanophora polyandra Griff in mice. Eur. J. Pharmacol. 616, 328-333.

32. Van Hoek, B. 2004. Non-alcoholic fatty liver disease: a brief review. Scand J. Gastroenterol. 241, 56-59

33. Wetterau, J. R., R. E. Gregg, T. W. Harrity, C. Arbeeny, M. Cap, F. Connolly, C. H. Chu, R. J. George, D. A. Gordon, H. Jamil, K. G. Jolibois, L. K. Kunselman, S. J. Lan, T. J. Maccagnan, B. Ricci, M. Yan, D. Young, Y. Chen, O. M. Fryszman, J. V. M. Logan, C. L. Musial, M. A. Poss, J. A. Robl, L. M. Simpkins, W. A. Slusarchyk, R. Sulsky, P. Taunk, D. A. Magnin, J. A. Tino, R. M. Lawrence, J. K. Dickson, Jr., and S. A. Biller. 1998. An MTP inhibitor that normalizes atherogenic lipoprotein levels in WHHL rabbits. Science 282, 751-754.

34. Wilcox, L. J., P. H. R. Barrett, R. S. Newton, and M. W. Huff. 1999. ApoB100 secretion from HepG2 cells is decreased by the ACAT inhibitor CI-1011: an effect associated with enhanced intracellular degradation of apoB. Arterioscler. Thromb. Vasc. Biol. 19, 939-949.

35. Yao, Z. and D. E. Vance. 1988. The active synthesis of phosphatidylcholine is required for very low density lipoprotein secretion from rat hepatocytes. J. Bid. Chem 263, 2998-3004.

36. Yao, Z., K. Tran, and R. S. McLeod. 1997. Intracellular degradation of newly synthesized apolipoprotein B. J. Lipid Res. 38, 1937-1953.

초록 : 고지방식이 비만쥐의 지방관련 단백질의 변화

서은희 · 한영 · 박소영 · 고형종 · 이혜정ᄎ

(동아대학교 의과대학 약리학교실)

과체중과 비만은 당뇨병, 고혈압, 고지혈증과 같은 신진 대사 질환의 발병과 강력하게 연관되어 있다. 비만의 원인은 여러가지가 있겠지만, 고지방식이는 비만의 원인 중 가장 중요한 요소 중 하나이다. 본 연구에서는 $\mathrm{C} 57 \mathrm{BL} / 6$ 생쥐에게 22주간의 고지방 식이를 주었으며, 이를 통해 비만과 고혈당을 유도하였다. 22주 후에 고지방 식이를 한 생쥐들에서 체중과 혈장 포도당 수준이 정상 식이를 한 생쥐들에 비해 크게 증가함을 관찰하였다. 복 막 내 당 부하 검사(IPGTT)에서도 고지방 식이를 한 생쥐들은 정상 식이를 한 생쥐들에 비해서 당 내성 이상 반응을 보여주었다. 이러한 결과들은 고지방식이가 $\mathrm{C} 57 \mathrm{BL} / 6$ 생쥐에서 비만 및 고혈당을 유도한다는 사실을 확 인시켜 주었다. 고지방식이군 생쥐들에서는 정상식이군의 생쥐들에 비해 혈장의 중성지방과 총 콜레스테롤의 양 이 증가됨이 관찰되었다. 간에서의 중성지방 및 총 콜레스테롤의 수준도 역시 증가하였다. 따라서, 간에서의 지질 대사가 어떻게 변하였는지를 알기 위해, 지질대사에 관련된 단백질들의 변화를 관찰하였다. 지방 합성과 관련된 효소들 중 FAS와 GPAT가 고지방식이 군에서 의미있게 증가 되어있었으며, 지방 수송에 관련하는 단백질 중에서 도 $\mathrm{ApoB}$ 및 $\mathrm{MTP}$ 의 큰 증가가 고지방식이군에서 관찰되었다. 흥미롭게도, 대사 조절 인자로 알려진 $\mathrm{AMPK}$ 의 단백질의 양과 인산화 정도는 정상식이군에 비해 고지방식이군에서 의미있게 증가되었음이 관찰되었다. 결론적 으로, 본 연구에서 우리는 고지방식이가 지질 합성과 지질 수송과정을 생리학적으로 증가시키지만, 역설적으로 $\mathrm{AMPK}$ 의 활성화를 유발한다는 것을 확인하였다. 